\title{
KUALITAS MOTILITAS DAN VIABILITAS SPERMATOZOA DARI SEMEN AFKIR SAPI LIMOUSIN PADA PENGENCER SUSU SKIM KUNING TELUR SITRAT DENGAN PENAMBAHAN BERBAGAI KADAR GLUKOSA
}

\section{QUALITY OF SPERMATOZOA MOTILITY AND VIABILITY FROM REJECTED LIMOUSIN BULL SEMEN DILUTED WITH SKIM MILK EGG YOLK SITRAT ADDED WITH VARIOUS LEVELS OF GLUCOSE}

\author{
Rudi Irvanto $^{1)}$,Hardijanto ${ }^{2)}$, Widya Paramita ${ }^{3)}$ Suherni Susilowati $^{4)}$, Tita \\ Damayanti L. 5), Erma Safitri' ${ }^{\text {() }}$ \\ ${ }^{1)}$ Student,${ }^{2,4,5,6}$ Veterinary Reproduction Department, ${ }^{3)}$ Veterinary Animal Husbandry \\ Department \\ Faculty of Veterinary Medicine, Airlangga University \\ irvantorudi@gmail.com
}

\begin{abstract}
Quality of spermatozoa motility and viability from rejected limousin bull semen diluted with skim milk egg yolk sitrat added with various levels of glucose. Glucose level used were $0 \%, 0,5 \%, 1,5 \%, 2,5 \%$, and 3,5\%. Writer was using on four years old Limousine bull. Bull semen used in this research was bull rejected semen with bellow $70 \%$ motility. Semen observation was done at 0 hour, 24 hours and 48 hours. Research design used in this study was completely randomized design with faktorial pattern with 5 replicates. Highest result in motility this research was showed at 24 hours with $30 \%$ value in glucose $2,5 \%$ treatment and 48 hours with $10 \%$ value. The lowest result showed in glucose $0 \%$ treatment at 24 hours and $0 \%$ at 48 hours. Highest result in viability showed on glucose 2,5\% treatment with $62,6 \%$ value at 24 hours and at 48 hours with $53,4 \%$ value. Lowest result in viability showed on glucose $0 \%$ treatment with $44,2 \%$ value at 24 hours and $31,4 \%$ value at 48 hours.
\end{abstract}

Keywords : Limousine bull, spermatozoa, motility, viability

\section{Pendahuluan}

Usaha peternakan di Indonesia membutuhkan perhatian khusus dalam kaitannya untuk mempertahankan dan meningkatkan populasi untuk mencapai program swasembada daging sapi dan peningkatan penyediaan pangan hewani yang aman, sehat, utuh dan halal. Meningkatnya jumlah penduduk dan adanya perubahan pola konsumsi serta selera masyarakat telah menyebabkan konsumsi daging sapi secara nasional cenderung meningkat. Selama ini kebutuhan daging sapi di Indonesia dipenuhi dari tiga sumber yaitu sapi lokal, sapi impor, dan daging impor (Hadi dan Ilham, 2000). Data statistik Peternakan dan Kesehatan Hewan tahun 2013 menyebutkan bahwa pada tahun 2012 Indonesia mengimpor daging sapi sebesar 39.419.157 kg (Dirjen PKH, 2013).

Diperkirakan jika tidak ada perubahan teknologi secara signifikan dalam proses produksi daging sapi dalam negeri serta tidak adanya peningkatan populasi sapi yang berarti, maka kesenjangan antara pro- duksi daging sapi dalam negeri dengan jumlah permintaan akan semakin melebar, sehingga berdampak pada volume impor yang semakin besar. Upaya yang dapat dilakukan untuk mengatasi kesenjangan tersebut, yaitu dengan meningkatkan efisiensi reproduksi dengan cara persilangan bangsa sapi Bos Indicus (sapi Persilangan Ongole) dengan bangsa sapi BosTaurus (sapi Limosin maupun sapi Simental), sehingga impor sapi dapat dikurangi (Ihsan dan Wahjuningsih, 2011). Solusi ini dapat dilaksanakan dengan menerapkan Inseminasi Buatan (IB) pada sapi potong (Kain et al., 2004).

Pada Inseminasi Buatan (IB) Semen yang ditampung mengalami beberapa proses sebelum diinseminasikan. Setelah ditampung semen aktif bergerak sehingga terjadi proses metabolisme, hal ini berakibat pada pengurangan energi yang digunakan untuk pergerakan sehingga pada akhirnya spermatozoa akan mati. Proses lebih lanjut setelah penampungan semen adalah penambahan pengencer. pengenceran se- 
men dilakukan untuk mengurangi kepadatan dan menjaga kelangsungan hidup spermatozoa. Syarat pengencer adalah menyediakan zat - zat makanan sel spermatozoa sebagai sumber energi dalam proses metabolisme dan tidak bersifat racun bagi spermatozoa, dapat melindungi spermatozoa dari kejut dingin (cold shock), menghambat pertumbuhan mikroba serta bersifat sebagai penyangga (Djanuar, 1985).

Upaya untuk memperoleh semen dengan kualitas baik diperlukan medium pengencer yang mampu memberikan nutrisi optimum bagi spermatozoa. Bahan yang dapat ditambahkan dalam pengencer antara lain protein lemak yang terdapat pada kuning telur (Ihsan, 2011). Ketersediaan sumber energi yang berasal dari karbohidrat merupakan salah satu prasyarat untuk pengencer semen yang baik. Karbohidrat memiliki beberapa fungsi, yaitu sumber energi bagi sperma selama inkubasi, memelihara tekanan osmotik cairan dan dapat bertindak sebagai krioprotektan.

Produksi semen yang melimpah terkadang tidak diseimbangi dengan kualitas spermatozoa yang baik, di BBIB sendiri untuk motilitas semen di bawah 70\% semen tersebut akan dibuang (afkir). Berdasarkan latar belakang tersebut di atas, maka perlu dilakukan penelitian untuk mengetahui motilitas dan viabilitas spermatozoa dari semen Afkir sapi Limousin dalam pengencer susu skim kuning telur sitrat dengan berbagai kadar glukosa.

\section{Materi dan Metode \\ Waktu dan Tempat Penelitian}

Penelitian ini dilaksanakan di BBIB (Balai Besar Inseminasi Buatan) Singosari Malang pada bulan Desember 2016.

\section{Bahan dan Materi Penelitian}

Sampel yang digunakan dalam penelitian ini adalah semen dari sapi Limousin yang berasal dari BBIB Singosari Malang yang berjumlah satu ekor, berumur \pm 4 tahun. Semen sapi afkir yang dipilih sesuai dengan persyaratan yaitu: Sapi sehat dengan bulu yang mengkilat serta tidak sakit.

Bahan Penelitian ini meliputi : semen afkir sapi Limousin, susu skim, kuning telur, glukosa $0,5 \%, 1,5 \%, 2,5 \%$, dan 3,5\%, vaselin, alkohol 70\%, penicilline, streptomisin, larutan pewarna Eosin-
Negrosin, $\mathrm{NaCl}$ fisiologis, air hangat, dan aquadest.

Peralatan yang digunakan dalam penelitian ini antara lain vagina buatan lengkap dengan tabung penampung berskala. termos, penangas air, gelas ukur, gelas beker, erlenmeyer, kertas $\mathrm{pH}$ indikator universal. rak tabung tabung reaksi, gelas objek, gelas penutup, pengaduk, pipet pasteur, spuit tuberkulin $1 \mathrm{ml}$, mikroskop cahaya dan timbangan mikro.

\section{Metode Penelitian \\ Penampungan Semen}

Penampungan semen dilakukan dua kali dalam seminggu, semen diperoleh dari semen sapi Limousin yang berlibido baik yang berada di Balai Besar Inseminasi Buatan (BBIB) Singosari Malang. Semua prosedur koleksi dilakukan secara legeartis.

Semen yang diperoleh melalui vagina buatan harus memiliki kualitas yang baik maka dilakukan pemeriksaan secara makroskopis dan mikroskopis. Pemeriksaan mikroskopis meliputi volume semen, warna, bau, dan konsistensi (kekentalan), Sedangkan pemeriksaan secara mikroskopik untuk mengevaluasi motilitas (gerakan individu spermatozoa) dan viabilitas spermatozoa.

\section{Uji Motilitas}

Penilaian ini didasarkan pada gerakan atau motilitas dan kecepatan dari spermatozoa. Gerakan spermatozoa yang di nilai adalah spermatozoa yang maju kedepan (progresif) karena gerakan spermatozoa yang memenuhi syarat adalah aktif maju kedepan sedangkan kecepatan spermatozoa dinilai dari spermatozoa yang memiliki kecepatan cepat karena kecepatan ini berhubungan dengan waktu bertemunya sel telur dari induk (Susilowati dkk, 2010).

$\%$ Motilitas Spermatozoa $=$ $\frac{\text { jumlah spermatozoa progresif }}{200} \times 100 \%$

\section{Uji Viabilitas}

Banyaknya spermatozoa yang hidup atau mati menentukan nilai suatu semen. Lapisan lipoid pada dinding sel dapat melindungi masuknya zat warna kedalam spermatozoa. Jadi spermatozoa yang hidup tidak akan terwarnai oleh zat warna, se- 
dangkan spermatozoa yang telah mati akan terwarnai.

$$
\begin{gathered}
\begin{array}{c}
\% \\
\text { jumlah spermatozoa hidup }
\end{array} \\
200
\end{gathered}
$$

\section{Perlakuan}

Perlakuan penelitian akan dilakukan sebagai beriku tini.

(P0) : semen + (susu skim kuning telur sitrat + tanpa glukosa) + antibiotik

(P1) : semen + (susu skim kuning telur sitrat + glukosa $0,5 \%)+$ antibiotik

(P2) : semen + (susu skim kuning telur sitrat + glukosa $1,5 \%)+$ antibiotik

(P3) : semen + (susu skim kuning telur sitrat + glukosa 2,5\%) + antibiotik

(P4) : semen + (susu skim kuning telur sitrat + glukosa 3,5\%) + antibiotik

Pemeriksaan setelah dilakukan pengenceran dilakukan setiap 0 jam, 24 jam dan 48 jam dengan 5 kali ulangan.

\section{Hasil dan Pembahasan \\ Keadaan Semen Segar}

Penentuan kelayakan semen Sapi Limousin dalam penelitian ini adalah pemeriksaan semen secara makroskopis dan mikroskopis. Pemeriksaan semen segar secara makroskopis meliputi pemeriksaan volume semen segar, warna semen segar, bau semen, konsistensi, derajat keasaman $(\mathrm{pH})$. Sedangkan untuk pemeriksaan mikroskopis meliputi konsentrasi semen serta motilitas dan viabilitas semen. Hasil evaluasi semen segar pada penelitian ini dapat dilihat selengkapnya pada tabel 4.1.

\section{Persentase Motilitas Spermatozoa Sapi Limousin}

Hasil dari pemeriksaan persentase motilitas dan viabilitas spermatozoa sapi Limousin yang telah diberikan perlakuan dapat dilihat dalam tabel dan diagram sebagai berikut.

Tabel 1. Rerata hasil pemeriksaan semen segar dari sapi Limousin

\begin{tabular}{cccccccc}
\hline \multirow{2}{*}{$\begin{array}{c}\text { Ulangan } \\
(\mathrm{n})\end{array}$} & \multicolumn{4}{c}{ Makroskopis } & \multicolumn{4}{c}{ Mikroskopis } & Konsentrasi \\
\cline { 2 - 6 } & Warna & $\mathrm{pH}$ & Konsistensi & $\begin{array}{c}\text { Volume } \\
(\mathrm{cc})\end{array}$ & $\begin{array}{c}\text { Gerakan } \\
\text { Massa }\end{array}$ & $\begin{array}{c}\text { Gerakan } \\
\text { Individu }\end{array}$ & Jt/ml \\
\hline 1 & $\begin{array}{c}\text { Putih } \\
\text { susu }\end{array}$ & 6,6 & Pekat & 6,4 & $2+$ & $35 \%$ & 1504 \\
2 & $\begin{array}{c}\text { Putih } \\
\text { susu }\end{array}$ & 6,6 & Pekat & 3,6 & $2+$ & $45 \%$ & 1160 \\
3 & $\begin{array}{c}\text { Putih } \\
\text { susu }\end{array}$ & 6,2 & Pekat & 5 & $2+$ & $40 \%$ & 1687 \\
4 & $\begin{array}{c}\text { Putih } \\
\text { susu }\end{array}$ & 6,4 & Sedang & 4,4 & $2+$ & $40 \%$ & 1365 \\
5 & $\begin{array}{c}\text { Putih } \\
\text { susu }\end{array}$ & 6,4 & Sedang & 5,8 & $2+$ & $60 \%$ & 1439 \\
Rerata & $\begin{array}{c}\text { Putih } \\
\text { susu }\end{array}$ & 6,4 & - & 5,04 & $2+$ & $44 \%$ & 1431 \\
\hline
\end{tabular}

Tabel 2. Rerata Persentase Hasil Pemeriksaan Motilitas Spermatozoa yang di tambahkan pengencer dalam setiap perlakuan dengan 5 kali ulangan.

\begin{tabular}{ccc}
\hline \multicolumn{3}{c}{ Motilitas Spermatozoa $(\%)($ Rerata \pm Standart Deviasi) } \\
\hline 0 jam & 24 jam & 48 jam \\
\hline $44^{\mathrm{a}} \pm 9.617$ & $4^{\mathrm{a}} \pm 4.183$ & $0^{\mathrm{a}} \pm 0$ \\
$44^{\mathrm{a}} \pm 9.617$ & $18^{\mathrm{b}} \pm 6.708$ & $6^{\mathrm{b}} \pm 5.477$ \\
$44^{\mathrm{a}} \pm 9.617$ & $22^{\mathrm{b}} \pm 9.082$ & $8^{\mathrm{b}} \pm 6.708$ \\
$44^{\mathrm{a}} \pm 9.617$ & $30^{\mathrm{b}} \pm 10.00$ & $10^{\mathrm{b}} \pm 11.180$ \\
$44^{\mathrm{a}} \pm 9.617$ & $27^{\mathrm{b}} \pm 11.51$ & $9^{\mathrm{b}} \pm 8.944$ \\
\hline
\end{tabular}


Hasil uji Faktorial menunjukkan adanya perbedaan yang tidak signifikan dalam setiap perlakuan. Uji Duncan dilakukan dalam uji lanjutan yang menunjukkan hasil bahwa P3 yaitu pengencer susu skim kuning telur sitrat dengan penambahan glukosa 2,5\% memberikan hasil tertinggi yaitu dengan hasil $30 \%$ pada pemeriksaan di 24 jam dan $10 \%$ pada pemeriksaan 48 jam, dan menunjukan perbedaan yang tidak signifykan pada P1,P2, dan P4 serta menunjukkan nilai motilitas terendah pada P0 yaitu pengencer susu skim kuning telur sitrat tanpa glukosa dengan nilai $4 \%$ pada pemeriksaan 24 jam dan $0 \%$ pada pemeriksaan 48 jam.

Kelompok P0 tanpa penambahan glukosa dalam pengencer (kontrol) menunjukkan hasil terendah dalam penelitian ini. Dikarenakan sumber energi untuk motilitas spermatozoa dalam penyimpanan semen segar $5^{0} \mathrm{C}$ hanya didapat dari susu skim kuning telur saja. Sehingga tersedianya ATP yang kurang mengakibatkan aktifitas kontraksi fibril-fibril pada ekor sperma menjadi tidak berfungsi untuk menimbulkan pergerakan (motilitas) pada spermatozoa.

Kelompok P1 yaitu berkadar glukosa $0,5 \%$ dan P2 dengan berkadar glukosa $(1,5 \%)$ pada pengencer susu skim kuning telur sitrat menunjukkan hasil yang berbeda nyata dengan P0.Penambahan glukosa $0,5 \%$ dan $1,5 \%$ itu belum optimal untuk motilitas spermatozoa, dikarenakan sumber energi yang dihasilkan belum mencukupi untuk pergerakan sepermatozoa. Selain itu Dilaporkan oleh Tambing dkk (2003) semakin panjang lama simpan pada suhu $5^{\circ} \mathrm{C}$ maka asupan nutrisi yang berasal dari pengencer semakin berkurang penurunan ini akan mempengruhi energi untuk daya hidup spermatozoa.

Kelompok P3 (berkadar glukosa sebanyak 2,5\%) pada pengencer susu skim kuning telur sitrat menunjukkan hasil yang tertinggi. Dalam pengencer ini proses pembentukan tenaga (ATP) yang berasal dari glukosa dapat berlangsung dengan baik yang dapat mendukung kontraksi fibril dan pergerakan atau motilitas ekor spermatozoa. (Rizal, 2008).
Kelompok P4 berkadar glukosa 3,5\% pada pengencer susu skim kuning telur sitrat, menunjukkan turunnya persentase motilitas spermatozoa dari kelompok P3 (berkadar glukosa 2,5\%). Besarnya kadar glukosa dalam pengencer kelompok ini akan memberi peluang pada pembentukan ATP dan metabolisme sel spermatozoa terjadi lebih cepat. Namun ternyata laju terbentuknya ATP dari hasil metabolisme spermatozoa (asam laktat) menjadi tidak seimbang. Meningkatnya asam lakt at yang menumpuk akan berpengaruh terhadap laju kurangnya dan rendahnya motilitas spermatozoa. (Hafez.,2000)

Hasil uji dalam Faktorial menunjukkan perbedaan yang nyata pada P0 dengan P1,P2,P3 dan P4.Uji Duncan dilakukan untuk mengetahui hasil tertinggi dan terendah dalam penentuan nilai viabilitas spermatozoa afkir yang di pengaruhi oleh pengencer susu skim kuning telur sitrat dengan berbagai kadar glukosa dan berbagai waktu pemeriksaan .Kelompok P0 yang bertindak sebagai kontrol dalam penelitian ini menunjukkan hasil yang terendah. Hal ini dikarenakan dalam pengencer susu skim kuning telur sitrat tidak di tambahkan glukosa. Sehingga sumber energi yang didapat hanya dari susu skim kuning telur dan yang digunakan untuk mempertahankan daya tahan hidup spermatozoa rendah.

Kelompok P1 yaitu susu skim kuning telur sitrat dengan kadar glukosa $0,5 \%$ dan P2 yaitu susu skim kuning telur sitrat dengan kadar glukosa 1,5\% mempunyai hasil optimal dan tidak berbeda secara signifikan dengan P3 dan P4 dalam mempertahankan viabilitas spermatozoa. Sama halnya dengan membran plasma sel lainnya, membran plasma spermatozoa tersusun oleh protein dan fosfolipid. Pada umumnya, sel akan menggunakan mekanisme tertentu untuk mencegah kerusakan membran yang tidak terkontrol (Mackie et al., 2001).

\section{Persentase Viabilitas Spermatozoa Sapi Limousin}

Kelompok P3 dengan penambahan glukosa $2,5 \%$ glukosa dalam pengencer 
Tabel 3. Rerata hasil pemeriksaan viabilitas spermatozoa afkir yang sudah di tambahkan pengencer dalam setiap perlakuan dengan 5 kali ulangan.

\begin{tabular}{ccc}
\hline \multicolumn{3}{c}{ Viabilitas Spermatozoa (\%) (Rerata \pm Standart Deviasi) } \\
\hline $\mathbf{0 ~ j a m}$ & $\mathbf{2 4}$ jam & $\mathbf{4 8}$ jam \\
$65.8^{\mathrm{a}} \pm 4.764$ & $44.2^{\mathrm{a}} \pm 3.962$ & $31.4^{\mathrm{a}} \pm 2.190$ \\
$65.8^{\mathrm{a}} \pm 4.764$ & $59.8^{\mathrm{b}} \pm 2.863$ & $49.6^{\mathrm{b}} \pm 5.683$ \\
$65.8^{\mathrm{a}} \pm 4.764$ & $60^{\mathrm{b}} \pm 4.000$ & $51.2^{\mathrm{b}} \pm 5.932$ \\
$65.8^{\mathrm{a}} \pm 4.764$ & $62.6^{\mathrm{b}} \pm 4.037$ & $53.4^{\mathrm{b}} \pm 6.148$ \\
$65.8^{\mathrm{a}} \pm 4.764$ & $60.4^{\mathrm{b}} \pm 3.847$ & $51.6^{\mathrm{b}} \pm 5.029$ \\
\hline
\end{tabular}

susu skim kuning telur sitrat dalam penelitian ini mampu menunjukkan hasil tertinggi. Penambahan glukosa $2 \%$ cenderung lebih mempertahankan daya hidup spermatozoa, menurut Maxwell dan Salamon (2000), gula dalam keadaan beku berbentuk seperti kaca (glass) yang tidak tajam, sehingga tidak merusak sel sperma secara mekanik. Menurut Bakas dan Disalvo (1991), gula dapat menjadikan membran plasma sel lebih stabil selama proses kriopreservasi, seperti yang dilaporkan pada berbagai jenis sel lain yang telah dibekukan.

Kelompok P4 yaitu dengan penambahan glukosa 3,5\% pada pengencer susu skim kuning telur sitrat mengalami penurunan motilitas pada spermatozoa Sapi Limousin. Penambahan sumber energi yang berlebih mengakibatkan spermatozoa bergerak sangat aktif. Pergerakan tersebut berpengaruh langsung pada peningkatan metabolisme pada spermatozoa. Sehingga asam laktat yang merupakan produk limbah hasil metabolisme menumpuk dan merupakan racun bagi spermatozoa yang mengakibatkan penurunan viabilitas (Hafez.,2000).

\section{Kesimpulan}

Penambahan kadar glukosa sebanyak $0 \%, 0,5 \%, 1,5 \%, 2,5 \%$ dan $3,5 \%$ pada pengencer susu skim kuning telur sitrat pada semen afkir Sapi Limousin mampu mempertahankan motilitas spermatozoa. Dengan menunjukkan hasil motilitas dan viabilitas tertinggi pada pengencer susu skim kuning telur sitrat yang dipengaruhi kadar glukosa sebanyak 2,5\%.

\section{Daftar Pustaka}

Bakas, L.S. and E.A. Disalvo. 1991. Effects of $\mathrm{Ca}^{2+}$ on the cryoprotective action of trehalose. Cryobiology 28: 347353

Direkterot Jenderal Peternakan dan Kesehatan Hewan . 2013. Statistik PKH 2013. Dirjen PKH Kementerian Pertanian.

Djanuar. 1985. Fisiologi Reproduksi dan Inseminasi Buatan pada Sapi. Gadjah Mada University Press. Yogyakarta 277

Hadi, P.U. dan N. Ilham. 2000. Peluang Pengembangan Usaha Pembibitan Ternak Sapi Potong di Indonesia Dalam Rangka Swasembada Daging 2005. PSE, Bogor.

Hafez, E. S. E. 2000. Semen Evaluation in Reproduction In Farm Animals. 7th edition. Lippincott Wiliams and Wilkins. Maryland, USA.

Ihsan, M.N. dan S. Wahjuningsih. 2011. Penampilan Reproduksi Sapi Potong Di Kabupaten Bojonegoro. Jurnal Ternak Tropika, 12 (2): 74-80.

Kaiin,E.M., M. Gunawan, S. Said dan B. Tappa. 2004. Fertilisasi dan Perkembangan Oosit Sapi Hasil IVF dengan Sperma Hasil Pemisahan. Pros. Seminar Nasional Teknologi Peternakan dan Veteriner. Bogor, 45 Agustus 2004. Puslitbang Peternakan, Bogor. $21-25$.

Mackie, A.R.P., P. S. James, S. Ladha and R. Jones. 2001. Diffusion Barriers in Ramand Boar Sperm Plasma Membranes : Directionality of Lipid Diffusion Across The Posterior Ring. 
Biology Reproduction. Society for The Study of Reproduction, Inc.

Maxwell WMC, and Salamon S. 2000. Storage of ram semen. J. Anim. Repro. Sci. 62: 77-111.

Rizal, M. dan Herdis. 2008. Inseminasi buatan pada sapi. Penerbit penebar swadaya. Jakarta.
Tambing, S.N., Mozes R. Toelihere, Tuty L. Yusuf, Bambang Purwantara, I Ketut Sutama, Polmer Z. Situmorang 2003. Kualitas Semen Beku Kambing Saanen Pada Berbagai Jenis Pengencer Semen. Jurnal Hayati. 10 (4): 146-150. 